\title{
RELATIONS BETWEEN THE ABILITY OF MATHEMATICAL CREATIVE THINKING AND INTEREST IN LEARNING MATHEMATICS HIGH SCHOOL STUDENTS USING THE METHOD OF DISCOVERY LEARNING THROUGH RECIPROCAL TEACHING APPROACH
}

\author{
Bima Gusti Ramadan ${ }^{1}$, Muhammad Yusuf Firdaus ${ }^{2}$, Rippi Maya ${ }^{3}$ \\ ${ }^{1,2,3}$ IKIP Siliwangi, Jalan Terusan Jenderal Sudirman Cimahi, Cimahi Tengah, Kota Cimahi \\ bemgusti7@gmail.com ${ }^{1}$, muhammadyusuf4189@gmail.com ${ }^{2}$, rippimaya@gmail.com ${ }^{3}$
}

Received: Apr 25 ${ }^{\text {th }}$, 2019; Accepted: Jul 4 ${ }^{\text {th }}, 2019$

\begin{abstract}
This study aims to examine how the relationship between mathematical creative thinking skills and students' learning interest in learning uses discovery learning methods through the reciprocal teaching approach. The method used in this study is an experimental method with a control group design pretest posttest. The population in this study were all SMAN in Cimahi City, while class samples were taken in random classes. Class XI IPA 1 was chosen as the experimental class and class XI IPA 2 was chosen as the control class. The experimental class is given learning using the discovery learning method through the reciprocal teaching approach while the control class is given regular learning. The results showed that both classes had a positive and significant relationship between mathematical creative thinking skills and students' learning interest in mathematics learning.
\end{abstract}

Keywords: Creative Thinking, Interest Learn, Discovery, Reciprocal Teaching Approach

\begin{abstract}
Abstrak
Penelitian ini bertujuan untuk menelaah bagaimana hubungan antara kemampuan berpikir kreatif matematik dengan minat belajar siswa dalam pembelajaran yang menggunakan metode discovery learning melalui pendekatan reciprocal teaching. Metode yang digunakan dalam penelitian ini adalah metode eksperimen dengan desain kelompok kontrol pretes postes. Populasi dalam penelitian ini adalah seluruh SMAN di Kota Cimahi, sedangkan sampel kelas diambil secara acak kelas. Kelas XI IPA 1 terpilih sebagai kelas eksperimen dan kelas XI IPA 2 terpilih sebagai kelas kontrol. Kelas eksperimen diberikan pembelajaran menggunakan metode discovery learning melalui pendekatan reciprocal teaching sedangkan kelas kontrol diberikan pembelajaran biasa. Hasil penelitian menunjukan bahwa kedua kelas terdapat hubungan yang positif dan signifikan antara kemampuan berpikir kreatif matematik dan minat belajar siswa dalam pembelajaran matematika.
\end{abstract}

Kata Kunci: Berpikir Kreatif, Minat Belajar, Pendekatan Reciprocal Teaching

How to Cite: Ramadan, B.G., Firdaus, M.Y., \& Maya, R. (2019). Relations Between The Ability of Mathematical Creative Thinking and Interest In Learning Mathematics High School Students Using The Method of Discovery Learning Through Reciprocal Teaching Approach. JIML, 2 (1), 9-XX.

\section{INTRODUCTION}

Krathwohl (Fardah, 2012), reveals that the taxonomy of educational goals compiled by Bloom is a framework for classifying expected or intended learning outcomes for students. Bloom's taxonomy was then revised by Anderson and Krathwohl and gave a new dimension, among others, remember, understand, apply, analyze, evaluate, and create. The highest goal is to 
10 Ramadan, Firdaus \& Maya, Relations Between The Ability of Mathematical Creative Thinking and Interest In Learning Mathematics High School Students Using The Method of Discovery Learning Through Reciprocal Teaching Approach

create and need the ability to think creatively to achieve it. This ability is needed in the future of each student.

In Permendiknas No. 22 of 2006 concerning the Competency Standards and Basic Competencies of Curriculum 2006 (Purwaningrum, 2017), it was stated that mathematics needs to be given to all students starting from elementary school to equip students with the ability to think logically, analytically, systematically, critically and creatively and the ability cooperate. Reality in the field according to Munandar (Darusman, 2016), that education in schools is more oriented to the development of intelligence (intelligence) rather than the development of creativity, while both are equally important to achieve success in learning and in life. Suriany (2016), the low quality of learning, shows the ineffectiveness of mathematics learning in the classroom, one of which is due to teacher limitations in providing opportunities for students to develop their abilities, teachers should provide more opportunities for students to go through the learning process itself.

According to Ruseffendi (2006), Mathematics is the queen of science, servant of science, art, language, human activities, deductive studies, and inductive studies. Mathematics as part of the curriculum in schools, plays a very important role in efforts to improve competent graduates who are expected to be useful in society. Not only that, mathematics is taught in schools because it is an indirect coaching which is to educate the nation. Nuriadin \& Perbowo (2016), Studying mathematics, can be used as a means to develop the ability to think and solve calculation problems. Like when students do count operations on fractions. Maybe adults will easily state that $1 / 4$ has a value equal to .25 , but some children sometimes have difficulty understanding that the two values actually have the same value

According to Yenni \& Putri (2019), Creativity is one of the national education goals according to the 2003 National Education System Law. Creative mathematics is still a problem for junior high school students. Students have not achieved this ability because of a variety of things. One of them is the existence of a disturbance or obstacle in students in learning mathematics because of the view that mathematics is a difficult subject to understand. This assumption can weaken the learning spirit of students so that they will become lazy in learning mathematics. According to Sumarmo (Istianah, 2013), the importance of critical and creative thinking skills is trained to students, supported by a vision of mathematics education that has two directions of development, namely meeting the needs of the present and the future. In learning mathematics, students are often faced with a complicated problem or a problem that is not routine. Therefore creative thinking in mathematical learning is very necessary. Creative thinking is closely related to critical thinking. Both are very basic human abilities, which can encourage someone to always look at each problem critically and try to solve it creatively.

The ability to think creatively is indispensable in facing increasingly complex problems in the future. Pucio and Murdock (Sumarmo, Hidayat, Zukarnaen, Hamidah, \& Sariningsih, 2012) argue, the use of the term creative thinking and creativity is often exchanged. Creativity is an umbrella construct as a creative product of creative individuals, contains stages of creative thinking processes, and a conducive environment for creative thinking to take place that contains aspects of cognitive, affective, and metacognitive skills. Ruseffendi (Choridah, 2016), states that creative people are not only good for themselves but also useful for others. 
Rahman (2014), The ability of mathematical creative thinking is the ability in mathematics which includes four abilities, namely: fluency, flexibility, authenticity and elaboration.

In fact, on the field students often find it difficult to do math problems. Students still feel confused, unfamiliar and have not been able to solve non-routine problems or questions that are required for higher-order thinking. Because most students are accustomed to solving routine questions and have not been able to develop their thinking processes widely with nonroutine questions. Changes need to be done in order to achieve optimal results, the role of the teacher is needed to provide more mathematical problems that can develop students' creative thinking abilities. Thus, one of the things that needs to be improved is the ability to think creatively in mathematics. In line with Eftafiyana, Nurjanah, Armania, Sugandi, \& Fitriani (2018), Based on the results of interviews with middle school students more students felt a lack of motivation to learn mathematics, because they held that mathematics was a scary lesson haunted by various formulas. The broken spirit of students in learning mathematics, can affect the expected learning optimally and the fact that students often forget that learning is important.

Other facts in the field show that the ability of mathematical creative thinking of high school students in Cimahi City is still very low. This can be seen from the results of interviews of researchers in some class XI teachers of senior high schools in Cimahi City, that the ability to think creatively in mathematical students of high school students in Cimahi is still low. Given the importance of the activities and creativity of these students, it is necessary to implement a learning strategy in schools that can develop and enhance student activity and creativity. How to choose a strategy in teaching needs to be adjusted to the material being taught so that students are not bored with learning procedures that never change and cause saturation. Not only that, the research of Tarida, Ibrahim, \& Anggreini (2015), entitled, Enhancing Students' Creative Thinking Abilities through the Indonesian Realistic Mathematics Education Approach, also shows the low ability to think creatively.

Previously, it was explained that the lack of ability in the cognitive aspects of mathematical creative thinking was allegedly due to a lack of motivation to learn or it could be called a lack of affective aspects, namely interest in learning. Therefore cognitive aspects, namely the ability to think creatively mathematically are important, and the affective aspects, especially interest in learning, are also important. Aside from being explained previously, this is confirmed by Purnama (2016), that interest is very influential with the achievements that students will get. With a high interest in learning, the process of teaching and learning activities will be more enjoyable so students do not feel burdened. According to Usman (Kartika, 2014), the conditions of teaching and learning are effective is the interest and attention of students in learning. Daniyati \& Sugiman (2015), in addition to verbal ability and interpersonal skills, interest is also closely related to student learning achievement. Interest is one of the factors that can affect one's efforts. If someone feels they have no interest in mastering knowledge, then it cannot be expected that students will study diligently and succeed. Interest is a trait that tends to settle on someone. Interest has a huge effect on learning. Students who have high interest, will pay more attention to the lesson. Students who have an interest in teaching and learning activities will try harder than students who have less interest. High interest that students have towards a subject, allows students to give high attention to those subjects so as to enable them to have high achievements. Therefore to achieve high achievement, in addition to intelligence, student interest is also needed, because without interest the teaching and learning process runs less effectively. 
12 Ramadan, Firdaus \& Maya, Relations Between The Ability of Mathematical Creative Thinking and Interest In Learning Mathematics High School Students Using The Method of Discovery Learning Through Reciprocal Teaching Approach

According to Getzels (Ismanto \& Hartono, 2014), interest is a feeling / tendency that is organized through experiences that encourage someone to look for objects, activities, understanding, skills or goals attentively. The definition of interest in Slameto (Nurhasanah \& Sobandi, 2016), is a feeling of preference, interest, attention, focus, perseverance, effort, knowledge, skill, motivation, behavior control, and the results of the interaction of someone or individual with certain content or activities. Furthermore Keke T. Aritonang (2008), interest in learning has a huge effect on learning outcomes because with someone's interest will do something that interests him.

According to Ruseffendi (2006), the choice of teaching methods must also consider the goals, environmental conditions, and students themselves. In overcoming material that requires student activity in learning, a learning strategy is needed that can arouse student activity in asking questions, raising problems, and making mathematical problem solving together with groups. According to Eftafiyana et al. (2018), the problems in mathematics learning that have been described previously must be addressed immediately, one of which is to be creative and innovative teachers who can make mathematics learning fun, more interesting, not boring and liked by students. In addition, in the learning activities the teacher is only a motivator and facilitator, while learning must be student-centered so that the classroom atmosphere comes alive.

In addition, Hadi (Haris \& Abadi, 2013) stated that the mathematics learning process that had occurred so far had not been as expected. The characteristic practice of education so far is teacher-centered learning. The teacher delivers lessons using the weak or expository method, while students record them in a notebook. The dominance of the teacher in the learning process causes the tendency of students to be more passive so that they wait for the teacher's presentation rather than looking for and finding their own knowledge, skills or attitudes they need. Learning mathematics like this causes students to experience difficulties in understanding abstract subject matter. According to Gazali (Gazali \& Atsnan, 2018), in learning activities, including mathematics learning, if the teacher can associate the material discussed with the student's condition, either hobbies or student needs, cognitive development, daily environment, and provisions that students already have, it will have a positive impact on students, namely learning is done in learning a mathematical concept to be fun

The way to overcome students 'displeasure in increasing their interest in learning about mathematics learning is to choose a teaching approach that can stimulate, direct, shape students' active learning and students can develop and improve their mathematical creative thinking abilities. And one of the ways is by creating a learning atmosphere that is in accordance with the conditions of the school environment. A pleasant learning atmosphere is expected to be able to spur students' enthusiasm, so that eventually the mathematical abilities that students get will also be better. One strategy that is considered to improve the ability to think creatively in mathematics is the method of discovery learning through the reciprocal teaching approach.

\section{METHOD}

This research uses experimental methods, where the population is a whole high school students at one school in the city of Cimahi and taken samples of two random class, namely class XI IPA 1 as first class (experimentation) with Discovery methods Approach to learning 
through Reciprocal Teaching and Class XI IPA 2 as second class (control) use ordinary learning. Instrument capabilities of mathematical creative thinking and learning motivation scale instruments are used for this research. Score scale is then transformed using the Method of Sucsesive Interval (MSI), and then tested using correlation Pearson Product Moment.

\section{RESULTS AND DISCUSSION}

\section{Results}

\section{Creative thinking ability and interest in Learning Mathematics}

Data obtained from this research is data pretes and postes. Pretes data used to know the ability of mathematical creative thinking of students beginning before the given action, whereas data postes used to achievement of mathematical creative thinking ability of the students after the given action. From the data the next postes pretes and retrieved data gain to see an increase in the ability of the creative thinking, the implementation method of discovery learning through reciprocal teaching approach. To better facilitate in analyzing data results pretes and postes, here presented the results of the statistics data description pretes, postes and n-gain the ability of mathematical creative thinking of students.

Table 1. Description of Statistics

\begin{tabular}{|c|c|c|c|c|c|c|c|}
\hline \multirow[t]{2}{*}{ Variabel } & \multirow[t]{2}{*}{ Stat } & \multicolumn{3}{|c|}{$\begin{array}{l}\text { The method of Discovery } \\
\text { Learning through Reciprocal } \\
\text { Teaching Approach }(n=36)\end{array}$} & \multicolumn{3}{|c|}{$\begin{array}{l}\text { Regular Learning } \\
\qquad(\mathrm{n}=36)\end{array}$} \\
\hline & & Pretes & Postes & Gain & Pretes & Postes & Gain \\
\hline \multirow[t]{3}{*}{ KBK } & $\bar{x}$ & 20.31 & 35.25 & .50 & 19.61 & 27.75 & .26 \\
\hline & $\%$ & 40.61 & 70.50 & 50.47 & 39.22 & 55.50 & 26.48 \\
\hline & $\mathbf{S}$ & 2.012 & 2.18 & .05 & 2.032 & 3.34 & .12 \\
\hline \multirow[t]{3}{*}{ MB } & $\bar{x}$ & - & 82.47 & - & - & 79.17 & - \\
\hline & $\%$ & - & 68.73 & - & - & 65.97 & - \\
\hline & S & - & 10.2 & - & - & 8.58 & - \\
\hline
\end{tabular}

Description:

KBK : Creative thinking ability

SMI KBK is 50

MB : Learning interest

SMI MB is 120

The analysis of the data in table 1 yields the following findings. On pretest, there is no difference in the ability of mathematical creative thinking of students in both the learning and the ability is very low (about 20.31 and ideal score of 19.61 50). After learning by using the method of discovery learning through reciprocal teaching approach, the ability of mathematical creative thinking $(70.50 \%$ of the score, with ngain $=.50)$ belongs to the medium, and this is better than ability creative thinking mathematics students who use ordinary learning $(55.50 \%$ of the score, with ngain $=.26)$. This indicates the ability of mathematical creative thinking of students class experiments better.

In Table 1 it can be seen also interest students in classes that get a learning method using discovery learning through reciprocal teaching approaches that obtain a score an average of $82.47(68.73 \%)$ who belongs to the category of being, this is better than students who get regular study with an average score of 65.97 (79.17\%) who belongs to the category of being. 
14 Ramadan, Firdaus \& Maya, Relations Between The Ability of Mathematical Creative Thinking and Interest In Learning Mathematics High School Students Using The Method of Discovery Learning Through Reciprocal Teaching Approach

Classification results obtained using learning interest calculation of Quartil, and the results were as follows:

Table 2. Classification Learning Interest

\begin{tabular}{cc}
\hline Kategori & Klasifikasi \\
\hline High & $\bar{x} \geq 91.75$ \\
Medium & $76.50 \leq \bar{x}<91.75$ \\
Low & $\bar{x}<76.50$ \\
\hline
\end{tabular}

The hypothesis in this study: "there is a positive relations between the ability of mathematical creative thinking and learning interest of students in learning using the method of SMAN discovery learning through reciprocal teaching approach".

\section{Test Correlation capabilities of creative thinking and interest in Learning Mathematics}

After a test of normality distribution data mathematical logical thinking ability, mathematical ability of critical thinking, and the ability of mathematical creative thinking that the data obtained are not Gaussian. Therefore, the mean difference in testing capabilities in the top third is done using Pearson Correlation Test.

The existence of a correlation between the ability of mathematical creative thinking and interest in learning mathematics are analyzed using a table of correlation between two variables such as presented in Table 3 and Table 4 below:

Table 3. Test Results Correlation between the Ability of Mathematical Creative Thinking and Interest in Learning Mathematics Classroom Experiments

\begin{tabular}{lccc}
\hline & Postes Creative & $\begin{array}{c}\text { Thinking } \\
\text { Experiments }\end{array}$ & $\begin{array}{c}\text { Interest In Learning } \\
\text { Experiments }\end{array}$ \\
\hline Postes Creative & Pearson Correlation & 1 & $.052^{* *}$ \\
Thinking & Sig. (2-tailed) & & .000 \\
Experiments & $\mathrm{N}$ & 36 & 36 \\
\hline Interest In & Pearson Correlation & $.052^{* *}$ & 1 \\
Learning & Sig. (2-tailed) & .000 & 36 \\
Experiments & $\mathrm{N}$ & 36 & \\
\hline
\end{tabular}

Table 4. Test Results Correlation between the Ability of Mathematical Creative Thinking and Interest in Learning Mathematics Classroom Control

\begin{tabular}{lccc}
\hline & & $\begin{array}{c}\text { Postes Creative } \\
\text { Thinking Control }\end{array}$ & $\begin{array}{c}\text { Interest In } \\
\text { Learning Control }\end{array}$ \\
\hline Postes Creative & Pearson Correlation & 1.000 & $.990^{* *}$ \\
Thinking Control & Sig. (2-tailed) &. & .000 \\
& $\mathrm{~N}$ & 36 & 36 \\
\hline Interest In & Pearson Correlation & $.990^{* *}$ & 1,000 \\
Learning Control & Sig. (2-tailed) & .000 &. \\
& $\mathrm{~N}$ & 36 & 36 \\
\hline
\end{tabular}


The results of the analysis of Table 3 above, it turns out that the value of the correlation between the results of creative mathematical thinking ability and interest in experimental class students learn of the significance .000 and value of .052. Because the value of their significance .000 less than .05 then there is a significant relations between the ability of mathematical creative thinking and interest in learning classroom experiments.

The results of other analysis as presented in Table 4, it turns out that the value of the correlation between the ability of mathematical creative thinking and student interest in the control class is 0.990 and a significance value of 0.000 . While the correlation value (r) obtained is 0.990 which means the level of correlation is very strong. Because the significant value of 0,000 is less than 0.05 , there is a significant relationship between the ability of mathematical creative thinking and interest in learning the control class.

\section{Discussion}

After the learning process in the classroom methods of discovery learning through rechiprocal approach teaching and learning with total class meetings as much as 12 times, and then given a second class on the postes. Granting postes aims to find out if there is a positive relationship between the ability of mathematical creative thinking and learning interest of students in learning using the method of SMAN discovery learning through reciprocal teaching approach. The results of the creative thinking ability and postes now interest in learning mathematics grade experiments showed there was no significant relationship between the ability of mathematical creative thinking and interest in learning. In contrast to the results of mathematical creative thinking ability postes and interest in learning mathematics grade control shows there is a significant relationship between the ability of mathematical creative thinking and interest in learning.

In both classes, good control class or classes of experiments going on a different relationship between the ability of mathematical creative thinking and learning interest owned by students. However, if the difference in class experiments using methods of discovery learning through reciprocal teaching approach, the results of the given question form and postes after learning by using visible above the average of the results of the postes and the now late students who use ordinary learning. The difference with the class of the control, if the ability of mathematical creative thinking student owned less, then so are the interest owned by students. Based on the results of the analysis have been presented, we can pull the conclusion that learning maths by using methods of discovery learning through reciprocal teaching approach will improve the ability of mathematical creative thinking of students, and also have a direct impact on improving the learning dimilki interest by students.

\section{CONCLUSION}

There is a positive and significant relationship between creative thinking ability of Mathematics with an interest in learning of students in mathematical learning to acquire learning method using discovery learning through reciprocal teaching approach.

There is a positive and significant relationship between creative thinking ability of Mathematics with an interest in learning to students who earn a regular learning. 
16 Ramadan, Firdaus \& Maya, Relations Between The Ability of Mathematical Creative Thinking and Interest In Learning Mathematics High School Students Using The Method of Discovery Learning Through Reciprocal Teaching Approach

\section{REFERENCES}

Choridah, D. T. (2016). Peran Pembelajaran Berbasis Masalah Untuk Meningkatkan Kemampuan Komunikasi Dan Berpikir Kreatif Serta Disposisi Matematis Siswa Sma. Infinity Journal, 2(2), 194. https://doi.org/10.22460/infinity.v2i2.35

Daniyati, N. A., \& Sugiman. (2015). Hubungan Antara Kemampuan Verbal , Kemampuan Interpersonal, dan Minat Belajar dengan Prestasi Belajar Matematika The Relationship Among Verbal Ability, Interpersonal Ability, Interest in Learning, and the Mathematics Learning Achievement. Jurnal Pendidikan Matematika, 10(1), 50-60.

Darusman, R. (2016). Penerapan Metode Mind Mapping (Peta Pikiran) Untuk Meningkatkan Kemampuan Berpikir Kreatif Matematik Siswa Smp. Infinity Journal, 3(2), 164. https://doi.org/10.22460/infinity.v3i2.61

Eftafiyana, S., Nurjanah, S. A., Armania, M., Sugandi, A. I., \& Fitriani, N. (2018). Hubungan Antara Kemampuan Berpikir Kreatif Matematis Dan Motivasi Belajar Siswa Smp Yang Menggunakan Pendekatan Creative Problem Solving. TEOREMA: Teori Dan Riset Matematika, 2(2), 85. https://doi.org/10.25157/teorema.v2i2.1070

Fardah, D. K. (2012). Analisis Proses dan Kemampuan Berpikir Kreatif Siswa dalam Matematika Melalui Tugas Open-Ended. Kreano, Jurnal Matematika Kreatif-Inovatif, 3(2), 91-99. https://doi.org/10.15294/KREANO.V3I2.2616

Gazali, R. Y., \& Atsnan, M. F. (2018). Peningkatan Motivasi dan Minat Belajar Matematika Siswa Melalui Pendekatan Kontekstual dalam Pembelajaran Matematika yang Bermakna Increased Motivation and Interest in Student Mathematics Learning Through Contextual Approach in Meaningful Mathematics Lear. 12(2), 123-134.

Haris, A., \& Abadi, A. M. (2013). Keefektifan Pembelajaran Kooperatif Tipe TGT dan GI Ditinjau dari Ketercapaian Standar Kompetensi, Sikap, Minat Matematika. Pythagoras: Jurnal Pendidikan Matematika, 8(2), 109-119. Retrieved from http://journal.uny.ac.id/index.php/pythagoras/article/view/8930/pdf

Ismanto, \& Hartono. (2014). Keefektifan Model STAD dan Direct Learning Berdasarkan Prestasi dan Minat Belajar Matematika Materi Kesebangunan Bangun Datar The Effectiveness of the STAD and Direct Learning Models in Terms of Learning Achievement and Interest in Mathematics for Topic o. Jurnal Pendidikan Matematika, 9(2), 147-160.

Istianah, E. (2013). Meningkatkan Kemampuan Berpikir Kritis dan Kreatif Matematik Dengan Pendekatan Model Eliciting Activities (MEAs) pada Siswa SMA. Infinity Journal, 2(1), 43-54.

Kartika, H. (2014). Pembelajaran Matematika Berbantuan Software Matlab sebagai Upaya Meningkatkan Kemampuan Komunikasi Matematis dan Minat Belajar Siswa SMA. Jurnal Pendidikan Matematika, 2(1), 175. https://doi.org/10.22342/jpm.10.2.3637.93108

Keke T. Aritonang. (2008). Minat dan Motivasi dalam Meningkatkan Hasil Belajar Siswa. Jurnal Pendidikan Penabur, 7(10), 11-14. https://doi.org/10.1017/CBO9781107415324.004

Nurhasanah, S., \& Sobandi, A. (2016). Minat Belajar Sebagai Determinan Hasil Belajar Siswa Learning Interest as Determinant Student Learning Outcomes. Jurnal Pendidikan Manajemen Perkantoran, 1(1), 135-142.

Nuriadin, I., \& Perbowo, K. S. (2016). Analisis Korelasi Kemampuan Berpikir Kreatif Matematik Terhadap Hasil Belajar Matematika Peserta Didik Smp Negeri 3 Lurangung Kuningan Jawa Barat. Infinity Journal, 2(1), 65. https://doi.org/10.22460/infinity.v2i1.25

Purnama, I. M. (2016). Pengaruh Kecerdasan Emosional dan Minat Belajar Terhadap Prestasi 
Belajar Matematika Di SMAN Jakarta Selatan Indah. Jurnal Formatif, 6(3), 233-245.

Purwaningrum, J. P. (2017). Mengembangkan Kemampuan Berpikir Kreatif Matematis Melalui Discovery Learning Berbasis Scientific Approach. Refleksi Edukatika, 6(2), 145-157. https://doi.org/10.24176/re.v6i2.613

Rahman, R. (2014). Pengaruh Penggunaan Metode Discovery Terhadap Kemampuan Analogi Matematis Siswa SMK Al-Ikhsan Pamarican Kabupaten Ciamis Jawa Barat. Infinity, $3(1), 1-42$.

Ruseffendi, E. T. (2006). Pengantar kepada Membantu Guru Mengembangkan Kompetensinya dalam Pengajaran Matematika untuk Meningkatkan CBSA (Tarsito). Bandung.

Sumarmo, U., Hidayat, W., Zukarnaen, R., Hamidah, \& Sariningsih, R. (2012). Kemampuan dan Disposisi Berpikir Logis, Kritis, dan Kreatif Matematik (Eksperimen terhadap Siswa SMA Menggunakan Pembelajaran Berbasis Masalah dan Strategi Think-Talk-Write). Jurnal Pengajaran Matematika Dan Ilmu Pengetahuan Alam, 17(1), 17. https://doi.org/10.18269/jpmipa.v17i1.228

Suriany, E. (2016). Peningkatan Kemampuan Berpikir Kreatif Matematis Siswa Sma Melalui Pembelajaran Math-Talk Learning. Indonesian Digital Journal of Mathematics and Education, 3, 296-305.

Tarida, L., Ibrahim, \& Anggreini, Y. (2015). Peningkatan Kemampuan Berpikir Kreatif Siswa Melalui Pendekatan Pendidikan Matematika Realistik Indonesia. Seminar Nasional Matematika Dan Pendidikan Matematika UNY, 1087-1094.

Yenni, Y., \& Putri, S. E. (2019). Optimalisasi Kemampuan Berpikir Kreatif Matematis Siswa SMP Melalui Pembelajaran Everyone Is A Teacher Here. JNPM (Jurnal Nasional Pendidikan Matematika), 1(2), 334. https://doi.org/10.33603/jnpm.v1i2.483 